\title{
Relationship between Microphysical Properties of Convective Clouds and Lightning Activity in a Typical Thunderstorm in Sichuan Basin
}

\author{
Jun Chang ${ }^{1,3 *}$, Juan $\mathrm{Gu}^{2}$, Fei Ji ${ }^{1}$, Fei Chang ${ }^{4}$, Hajigul Sayit ${ }^{5}$ \\ ${ }^{1}$ College of Atmospheric Sciences, Lanzhou University, Lanzhou 730000, China \\ ${ }^{2}$ College of Air Traffic Management, Civil Aviation Flight University of China, Guanghan 618307, China \\ ${ }^{3}$ Sichuan Branch of China Meteorological Administration Training Centre, Chengdu 610000, China \\ ${ }^{4}$ Gansu Air Traffic Management Sub-bureau of CAAC, Lanzhou 730000, China \\ ${ }^{5}$ Xinjiang Meteorological Society, Urumqi 830002, China
}

Received: 12 February 2020

Accepted: 6 June 2020

\begin{abstract}
Synthesized X-band dual-polarization Doppler radar data and the ambient temperature are used to explore the correlation between the microphysical properties and lightning activity of thunderclouds. After pre-processing of the radar data via the $\mathrm{Z}_{\mathrm{H}}-\mathrm{K}_{\mathrm{DP}}$ correction, fuzzy logic-based classification of hydrometeors is conducted in a typical thunderstorm process in Sichuan basin, China. The results are combined with the cloud-to-ground (CG) lightning observation for a comprehensive analysis, which show significant correspondence between lightning flash and the solid microphysical particles. In low levels below the freezing level, the CG lightning activity corresponds with heavy rainfall, while it displays graupel or mixed ice-phase particles above the freezing level. The size of graupel echo coincides with the CG lightning activity largely. The CG lightning occurrence is strongly correlated with the convective intensity of thunderclouds, especially the ice-phase particles being dominated by graupel. The strong echo indicates the intensive CG lightning activity very well above the freezing level. Strong CG lightning activity often corresponds to a high cloud top and a large graupel area in the thunderclouds. Consequently, the region of mixed ice-phase particles, especially the region of mixed dry and wet graupel, can be regarded as an important spatio-temporal indicator of the CG lightning activity. Significant linkage between the microphysical properties and lightning activity is revealed above the freezing level in convective clouds in Sichuan basin, which provides a valuable indicator of lightning disasters for numerical weather prediction.
\end{abstract}

Keywords: microphysical properties of thundercloud, cloud-to-ground lightning, fuzzy logic algorithm, $\mathrm{X}$-band dual-polarization Doppler radar

*e-mail: changj18@1zu.edu.cn 


\section{Introduction}

Lightning flash is a result of the convection in thunderclouds that is related to the collisions between ice-phase particles carried by strong updrafts [1-6]. A couple of studies have shown that microphysical properties including graupel have a significant effect on the lightning activity in convective clouds [7-11]. Bruning et al. [12] found that lightning initiated shortly after the detection of graupel in thunderclouds. Dotzek et al. [13] classified that the majority of lightning activity occurs in the cloud regions where graupel particles are present, followed by those with snow and hail. The conclusions of Lund et al. [14] were consistent with Dotzek and Burning, which show lightning initiation in or near the cloud regions that contain graupel. Although it is evident that graupel particles are inextricably linked with the occurrence of lightning flash, detailed investigation is still needed regarding the nature of this relationship in a local place such as Sichuan basin at the lee of Tibetan plateau, because a couple of types of hydrometeors exists in thunderclouds besides the graupel.

Hydrometeor classification is a prerequisite for the understanding of microphysics in thunderclouds. Particle classification methods based on data analysis include typically decision tree, statistical decision function, clustering algorithm, neural network classifier and fuzzy logic algorithm. In a fuzzy logic algorithm, the member is not necessarily confined to specific value as in decision tree algorithm. In comparison with the statistical-decision method, fuzzy logic algorithm is advantageously simpler and easier to be represented by membership functions. Due to the insufficient samples of radar data, the self-training based neural network and clustering analysis method are not suitable for hydrometeor classification $[15,16]$. Consequently, the fuzzy logic algorithm, which is based on a hierarchical partitioning such that can solve the problem of threshold overlap in particle classification, is the most suitable hydrometeor classification method [17, 18]. Since the successful development of the high-precision dualchannel circular-polarization radar in the 1960s, this technology has been widely used in meteorological observations. The accuracy of dual-polarization radar observation is continuously increasing, that is sensitive to minute-level changes in the phase, orientation, spatial distribution and scale spectrum of hydrometeors in convective clouds. Dual-polarization radar has been successfully used in precipitation telemetering, particle phase identification, transport and diffusion of hydrometeors and the assessment of weather modification techniques [19-25].

Vivekanandan et al. [26], Liu and Chandrasekar [27], Hassan et al. [28], Thompson et al. [29] and Nicoletta et al. [30] have successfully applied the fuzzy logic algorithm in classification of ice-phase particles in clouds. Marzano et al. [31] identified 10 types of hydrometeors using an improved fuzzy logic hydrometeor classification method based on C-band dual-polarization radar data. Cao et al. [32] and Cheng et al. [33] established a fuzzy-logic based system respectively for the classification of hydrometeors. Using the T-function and the Beta membership function, respectively, in combination with the dual-polarimetric radar observations, they retrieved a total of 11-type hydrometeor particles. The ambient temperature, however, is not taken into account in the studies. Park et al. [34] classified the horizontal distribution of hydrometeors in a mesoscale convective system using a fuzzy-logic based system in addition to the rationality analysis of this method. Zhang et al. [35] examined the electrical characteristics and the distribution of precipitation particles in thunderclouds. The evolution characteristics of graupel and dry snow are found consistent with a series of processes which take place during thunderstorm development, maturation and attenuation, and that larger ice-phase particles such as graupel and ice crystals, which are more active during the development and maturation stage of a thunderstorm, play a vital role in the formation and distribution of charge regions. Wang et al. [36] also retrieved cloud particles using the asymmetric T-function, pointing out that the phase of the retrieved particles was in sufficient agreement with the sounding data. Ribaud et al. [37] proposed a fuzzy logic hydrometeor classification algorithm that allows six microphysical species to be distinguished without considering radar wavelengths.

Much of the above work focused on the effect of hydrometeors on the electric distribution and lightning flash, few on the vertical coupling of hydrometeors and lighting activity. A typical thunderstorm in Sichuan basin on July 8, 2013 is analysed in this paper to learn the microphysical properties of convective clouds and the relationship with lightning activity in the basin, based on lightning location observation and dual polarized radar data. The data set is shown in the next section, and algorithm of classification is shown then. In section 4, a brief introduce of a typical case is displayed. Analysis and the results are given in section 5. Finally, conclusion and summary appear.

\section{Data and Algorithm}

\section{Data Sources}

The lightning data was obtained from the Sichuan Lightning Detection Network, which consists of 18 stations in Sichuan province. The network is shared by Chengdu University of Information Technology, Sichuan Meteorological Bureau and Sichuan Lightning Protection Centre. The data include the records of time of occurrence, position, electric charge, intensity, current steepness, lightning energy, error and positioning method. The lightning detection network has a positional accuracy of $500 \mathrm{~m}$ and efficiency of up to $85 \%$ within the range enclosed by 18 stations [38]. 
Table 1. Main parameters of the X-band dual-Polarization Doppler radar.

\begin{tabular}{|c|c|}
\hline Item & Technical performance \\
\hline Operating frequency & $9370 \pm 20 \mathrm{MHz}$ \\
\hline Maximum Operation Range & $\geq 150 \mathrm{~km}$ \\
\hline Doppler detection distance & $\geq 100 \mathrm{~km}$ \\
\hline Altitude of detection & $0-20 \mathrm{~km}$ \\
\hline Azimuth & $0^{\circ}-360^{\circ}$ \\
\hline Elevation angle & $-2^{\circ}-90^{\circ}$ \\
\hline Echo intensity & $-15 \mathrm{~dB}-+75 \mathrm{~dB}$ \\
\hline Velocity & $\pm 24 \mathrm{~m} / \mathrm{s}$ \\
\hline Velocity spectrum width & $0-16 \mathrm{~m} / \mathrm{s}$ \\
\hline
\end{tabular}

It has been widely used by meteorological bureaus in China for business application and scientific study [3945].

The radar data in the present study consists of the $\mathrm{X}$-band dual polarization Doppler radar data in Sichuan basin on July 8, 2013. The Weather Surveillance Radar (WSR-88D) is located at the Chengdu University of Information Technology. Its main parameters are shown in Table 1. The dual-polarization Doppler radar provides highly accurate and reliable measurements, including horizontal reflectivity $\mathrm{Z}_{\mathrm{H}}$, differential reflectivity $\mathrm{Z}_{\mathrm{DR}}$, specific differential phase $\mathrm{K}_{\mathrm{DP}}$ and a correlation coefficient $\rho_{\text {. }}$. These parameters play a key role in the classification of hydrometeors in the thunderclouds. Because the X-band radar are highly susceptible to attenuation, which can cause large errors, attenuation correction was carried out in addition to the selection of very closed thunderstorms in the study.

\section{The Algorithms}

The X-band dual-polarization weather radar data are first pre-processed and then used for the thundercloud hydrometeor classification.

\section{Pre-process of Radar Data on 3-D Grids}

To facilitate the analysis of radar echo and radar reflectivity at a certain altitude, the X-band dualpolarization radar raw data with a volume-scanning period of $6 \mathrm{~min}$ is used for pre-process analysis so that to obtain 3-D gridded data. The raw data are originally organized in a polar coordinate. In the 3-D analysis, interpolation on the polar system is accomplished after the latitude, longitude and altitude of the grid points in a spherical coordinate being transformed to elevation angle, azimuth and radial distance. The reached 3-D gridded data are limited to $17 \mathrm{~km}$ vertically and $150 \mathrm{~km}$ horizontally with a resolution of $500 \mathrm{~m}$. Xiao et al. [46] displays an effective processing scheme to define the grid point value with horizontal nearest neighbour and vertical linear interpolation. The vertical interpolation reads

$f(r, a, e)=\left[w_{e_{1}} f\left(r, a, e_{1}\right)+w_{e_{2}} f\left(r, a, e_{2}\right)\right] /\left(w_{e_{1}}+w_{e_{2}}\right)$

...where $r$ is the radial distance, $a$ the azimuth and $e$ the elevation angle. The point $(r, a, e)$ lies between points $\left(r, a, e_{1}\right)$ and $\left(r, a, e_{2}\right)$. The weights $w_{e l}$ and $w_{e 2}$ at $\left(r, a, e_{1}\right)$ and $\left(r, a, e_{2}\right)$ are given respectively as

$$
\begin{gathered}
w_{e_{1}}=\left|e_{2}-e\right| /\left(e_{2}-e_{1}\right) \\
w_{e_{2}}=\left|e_{1}-e\right| /\left(e_{2}-e_{1}\right)
\end{gathered}
$$

\section{Fuzzy Logic Algorithm}

As a well-regarded nonlinear classification method [47-50], fuzzy logic method is used for classification of hydrometeors. The method consists of four steps, fuzzification, rule inference, aggregation and defuzzification [27]. Fuzzification involves assignment of the input polarization parameters to appropriate fuzzy sets based on their corresponding degrees of membership. The membership function value is between 0 and 1 . The closer the value is to 1 , the higher the degree that the parameter belongs to the fuzzy set. To establish the membership functions of each X-band radar parameter, He et al. [51] adjusted the C-band radar parameters and temperature ranges proposed by Keenan [52] to obtain 15 classification categories of precipitation particles, and also verified the results using the airborne Particle Measurement System (PMS) data. Using Keenan [52] as a reference, Liu et al. [53] simplified the classification algorithm in $\mathrm{He}$ et al. [51] to determine the ranges of X-band dual-polarization radar parameters for a couple of hydrometeors. The results are verified using field observations and airborne observations. In this study, a beta function [27] is used to describe the membership function. The fuzzy logic threshold in Liu et al. [53] is adopted for $\mathrm{X}$-band polarimetric radar parameters, which is used as a reference to classify 10 hydrometeors, i.e. drizzle rain (DR), rain (RA), dry snow (DS), dry crystal (DC), wet snow (WS), dry graupel (DG), wet graupel (WG), small hail $(\mathrm{SH})$, large hail $(\mathrm{LH})$ and rain with hail (RH). Rule inference acts to output fuzzy variables that based on certain rules of judgement. Aggregation is the process by which the membership function of each individual fuzzy set is used to infer the most reasonable attribution in the overall fuzzy region. Two commonly used aggregation methods are additive aggregation and product aggregation. Aggregation produces a fuzzy set, for which a single representative value, for example rain, ice crystal or hail, is obtained through the process of defuzzification. During precipitation, the horizontal reflectivity $Z_{H}$ and the differential reflectivity $Z_{D R}$ cause large errors as a result of attenuation, an effective attenuative correction is applied. The $\mathrm{Z}_{\mathrm{H}}-\mathrm{K}_{\mathrm{DP}}$ combined 
method proposed by $\mathrm{Hu}$ et al. [54] is used in this study for correction of the attenuated radar data [55], because it comprehensively makes use of the advantages and disadvantages of the $\mathrm{Z}_{\mathrm{H}}$ and $\mathrm{K}_{\mathrm{DP}}$ corrections.

In addition to the four $\mathrm{X}$-band polarization parameters, $\mathrm{Z}_{\mathrm{H}}, \mathrm{Z}_{\mathrm{DR}}, \mathrm{K}_{\mathrm{DP}}$ and $\rho$, temperature is taken as another essential parameter for the determination of hydrometeor particles. Phase transition of hydrometeors depends on the temperature at different altitudes. The temperature approximately decreases with height in the troposphere in a lapse rate of $6.49^{\circ} \mathrm{C} / \mathrm{km}$. If there is not enough sounding data, the temperature above freezing $\left(0^{\circ} \mathrm{C}\right)$ level $h_{1}$ is calculated using the lapse rate, whereas that below is calculated through linear interpolation based on the surface temperature and the $0^{\circ} \mathrm{C}$ level,

$$
T(h)=\left\{\begin{array}{l}
-6.49\left(h-h_{1}\right), h>h_{1} \\
-C_{1} h+T_{g}, h \leq h_{1}
\end{array}\right.
$$

...where $C_{1}=\left(T_{g}-T_{h_{1}}\right) / h_{1}$ and $T_{g}$ denotes the surface temperature. The $0^{\circ} \mathrm{C}$ level is usually determined using the sounding data.

\section{A Typical Case Analysis}

\section{Atmospheric Circulation Background}

The thunderstorm investigated in this study was a typical long-duration event with strong lightning activity. It developed in association with a mesoscale Southwest vortex and a shear line under the support of favourable high- and low-level jets on July 8, 2013. Two deep low-pressure systems appeared in high-latitude region. The low latitude, however, was controlled by the western Pacific subtropical high (WPSH) and the Indian Ocean high. The Sichuan basin is located at the western margin of the WPSH. The east-ward movement of a short-wave trough was prevented by the WPSH, which induced rapid development of the southwest vortex underlapped with the short-wave trough. Continuous transport of water vapour to the basin by the south-westerly flow from the Bay of Bengal and the South China Sea was shown at $700 \mathrm{hPa}$. Accumulation of unstable energy was a consequence of the vortex development in the basin. The thunderstorm affected the northwest part of Sichuan with a sudden heavy rainfall. The accumulated rainfall at Dujiangyan reached $721.4 \mathrm{~mm} / 12 \mathrm{hr}$. The sounding data revealed that the convective available potential energy (CAPE) dropped from $1635 \mathrm{~J} / \mathrm{kg}$ at $2000 \mathrm{BJT}$ (Beijing Time $=\mathrm{UTC}+8$ ) on July 8 , to $128 \mathrm{~J} / \mathrm{kg}$ at $0800 \mathrm{BJT}$ on July 9. The convective stability index and the Showalter index (SI) dropped both negative then, indicating the release of CAPE during the strong convective process.

\section{Characteristics of Cloud-to-ground Lightning Activity}

The cloud-to-ground (CG) lightning began at 1636 BJT on July 8 and ended at 0100 BJT on July 9. A total of 4,869 CG lightning flashes were observed in this period, including 285 positive CG lightning flashes and 4,584 negative CG lightning flashes that accounted for $94.1 \%$ of the total number of flashes. Evolution of the CG lightning activity was obtained by counting their number every 6 minutes during the selected period

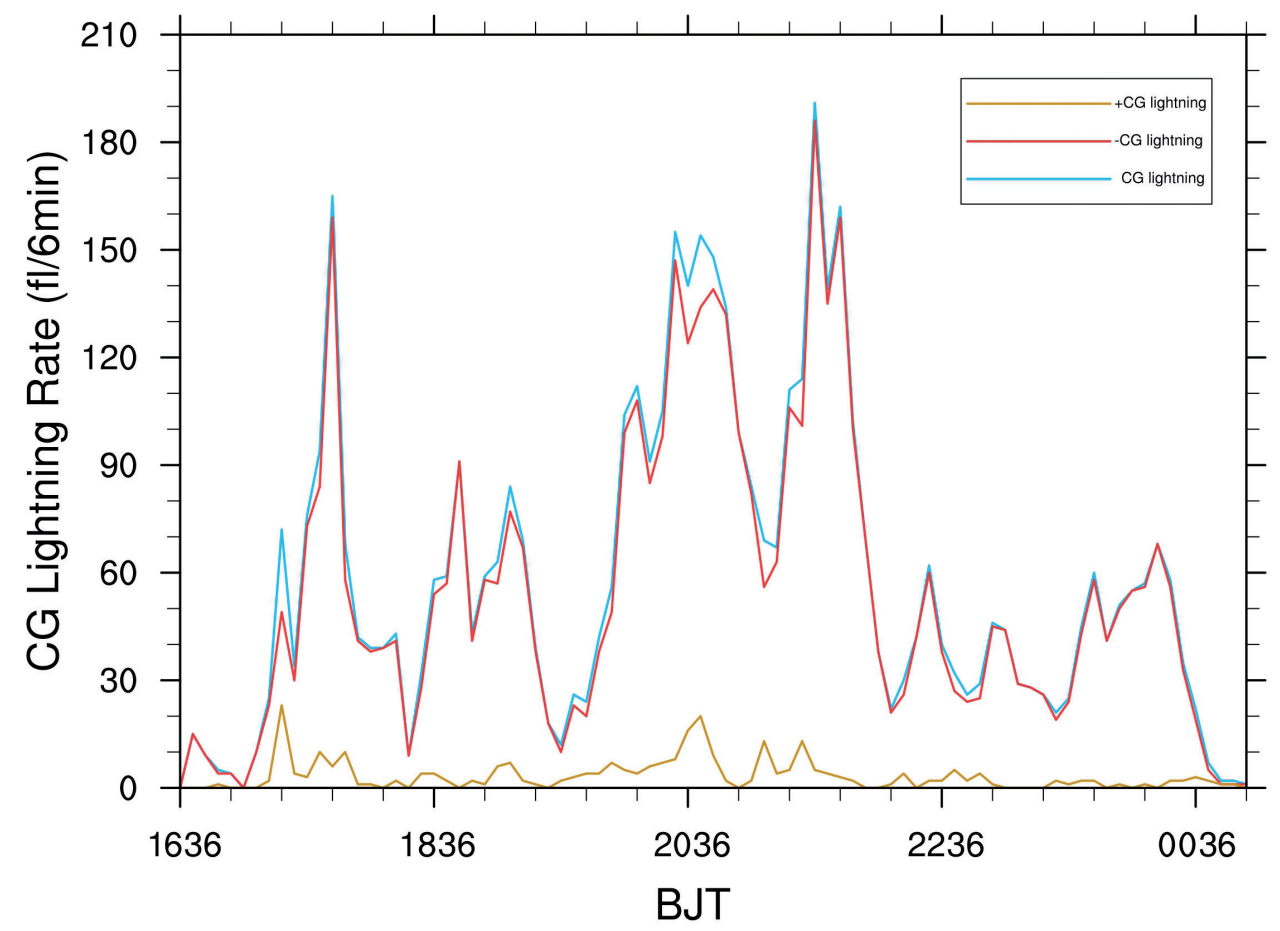

Fig. 1. Evolution of the CG lightning rate in the thunderstorm. 
(Fig. 1). It is evident in Fig. 1 that the CG lightning rate shows significant fluctuations. The trends of the total $\mathrm{CG}$ lightning and the negative $\mathrm{CG}$ lightning frequencies are almost completely consistent, and the peak values of the positive CG lightning are also relatively consistent with the peaks of the total lightning and the negative lightning flashes. Four high-rate periods of CG lightning, 1724-1754, 1836-1918, 2006-2100 and 2124-2154 BJT on July 8, is easily partitioned. The highest CG lightning rate occurred at 2136 BJT, with 194 strikes during a 6-min period.

Based on the illustration in Fig. 1, we select four peak cases of CG lighting activity in the highrate periods for the investigation of relationship to microphysical hydrometeors. The peak-activity cases selected are shown at 1748 (161 fl /6 min), 1848 (91 fl /6 min), 2030 (155 fl /6 min) and 2136 BJT (194 fl /6 min). Because of few CG lightning flash occurring at the weak-activity cases, we focus on the lightning flashes only in peak-activity periods. The classification, changes in thundercloud hydrometeors and the correlation to the CG lightning activity are shown in the subsequent sections.

\section{Spatial Location of CG Lightnings Related to the Radar Reflectivity}

Multi-peak series of the CG lightning rate is evidently shown in Fig. 1. The lightning flashes in the 4 peak-activity cases at 1748, 1848, 2030 and 2136 BJT July 8 were superimposed with the horizontal reflectivity at $3 \mathrm{~km}$ above ground level (AGL), as shown in Fig. 2. In Fig. 2, "+" and "-" represent positive and negative CG lightning flashes, respectively. The axis origin represents the location of radar. It is difficult to determine the height of origin of the CG lightning, superposition of radar echo at $3 \mathrm{~km}$ AGL is selected for the illustration of the CG lightning activity and the relationship with the radar echo. It is evident in Fig. 2a) that the thunderstorm consists of two cells at 1748 BJT. Most of the CG lightning flashes are located at the southern cell, which displays a strong banded convective area of radar reflectivity exceeding 40 dBZ. At 1848 BJT (Fig. 2b), the northern cell mostly dissipated, while the southern one enlarged with weakening intensity when moved northward. Most of the CG lighting flashes still took place in this cell. One hundred two minutes later at 2030 (Fig. 2c), the CG lightning flashes appeared in the strong convective region in north. Convection tended to be well organized band-like shape, in which several strong convective centres are revealed. In Fig. 2d), the most intensive lightning activity is shown in well accordance with the strong echoes. Both "+" and "-_" CG flashes appeared in the strong-echo region.

It is clear in Fig. 2 that the peak CG lightning flashes in the four selected moments mostly concentrated in the convective region with strong echoes. As the convection (a)

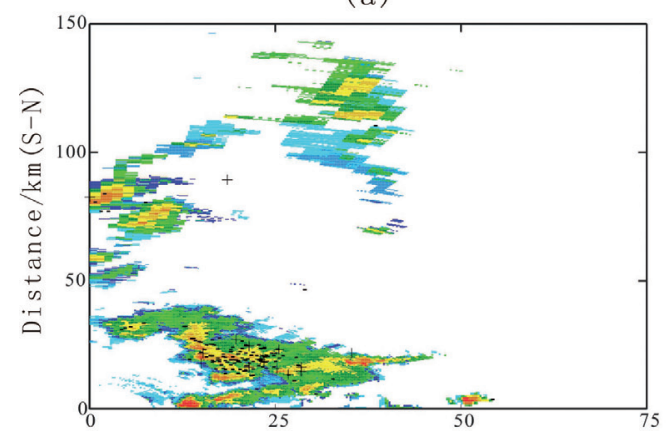

(c)

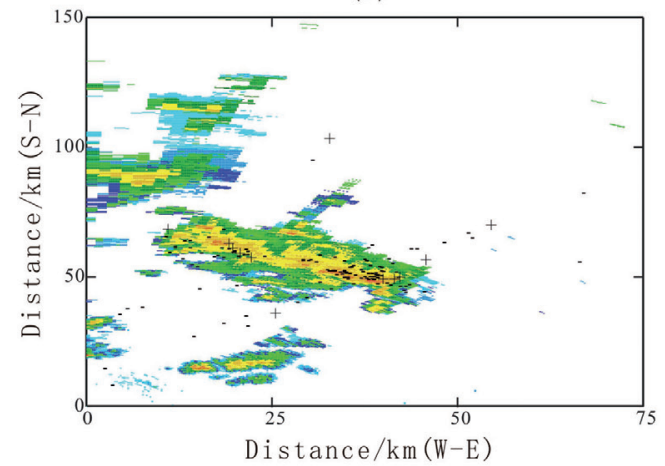

(b)

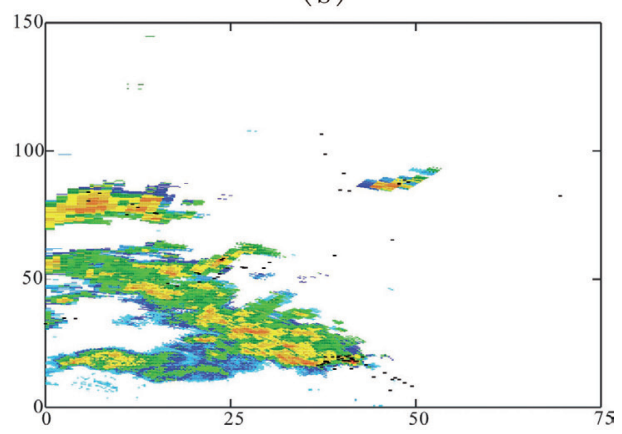

(d)

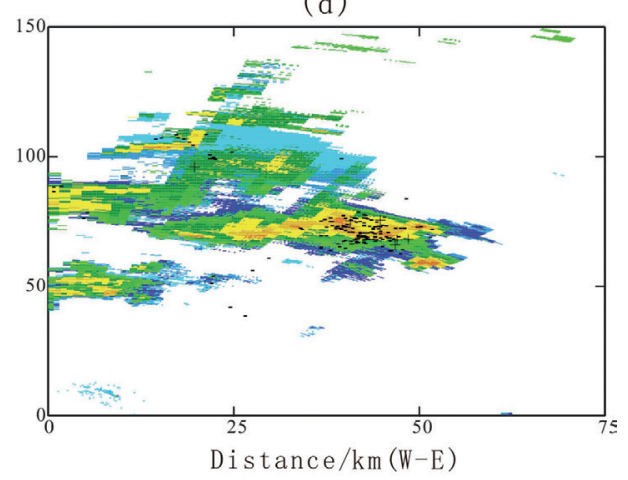

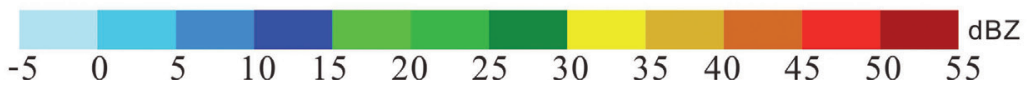

Fig. 2. Superposition of the radar reflectivity at $3 \mathrm{~km}$ AGL and the CG lightning distribution at four high-activity cases. a) 1748 , b) 1848 , c) 2030 and d) 2136 BJT July 8, 2013. 
organized well to a band shape, the CG lightning is always distributed in or around the 30-45 dBZ region. Mainly negatively charged CG lightning is found in the strong echo. A small number of positive lightning flashes occur primarily just outside of the strong echo region, where the reflectivity is $25-30 \mathrm{dBZ}$ that mostly shows anvil or stratiform clouds. These are consistent with the existing studies [56-59].

\section{Occurrence of CG Lightnings Related to the Strong Echo Volume}

Most of the CG lightning is confirmed in the 30-45 dBZ region in Fig. 2. Literatures show also that radar echo intensity of $40 \mathrm{dBZ}$ is suitable for lightning taking place [60-61]. Radar echo intensity over $40 \mathrm{dBZ}$ is therefore defined as strong echo in this study. Referencing the sounding data at 2000 BJT on July 8 , the height of freezing level is approximately $5 \mathrm{~km}$ AGL. Temporal series of the strong echo volume above $5 \mathrm{~km}$ AGL, in addition to the $\mathrm{CG}$ lightning activity, is illustrated in Fig. 3. The CG lightning activity is shown in close correspondence with the strong echo volume. The number of CG flashes increased rapidly when the strong echo enhanced with the convection development at 1648 BJT. Very similar temporal variation of them is observed in Fig. 3. Peaks of the CG lightning rate appear soon after strong echo volume above the freezing level shows its extremes at 1812, 1854, 2042 and 2106 BJT. When the strong echo shows its largest volume of $33 \mathrm{~km}^{3}$ at $2106 \mathrm{BJT}$ July 8, the highest CG lightning rate of $190 \mathrm{fl} / 6 \mathrm{~min}$ is then observed in the Fig. 3. The CG lightning rate drops immediately at the moments that the strong echo volume decreased. Few CG lightning was observed when strong echo disappeared above the freezing level.
After $2112 \mathrm{BJT}$, the echo volume was almost $0 \mathrm{~km}^{3}$, and the number of strikes was displayed approximately $50 \mathrm{fl} / 6 \mathrm{~min}$. Because of the weak updraft, the noninductive electrification between hydrometeor particles weakened, and the CG lightning ceased rapidly. Even though a limited leading time is observed, the strong echo volume serves as a good indicator of the strengthening and weakening of the CG lightning activity. The strong echo above the freezing level is thus an important factor in predicting the CG lightning activity.

\section{Linkage of CG Lightning with Cloud Microphysical Properties}

Carey et al. [62] demonstrated that radar echo volume can provide altitude information regarding reflectivity above the freezing level; it also can reflect the intensity of updraft regions. The reflectivity information of a single volume scan can comprehensively reflect the size and concentration of hydrometeors in a thundercloud at any given grid point. Because a close relationship between the lightning activity and the ice particle content of thunderclouds has been confirmed, there must also be a close relationship between the thunderstorm lightning activity and the radar echo volume above freezing level. The radar echo volume is expected to display the microphysical properties of thunderclouds.

\section{The CG Lightning in Relationship to Hydrometeors at Different Heights}

\section{At $3 \mathrm{~km}$ AGL}

The spatial distribution of hydrometeors in thunderclouds directly affects the charge structure in thunderclouds and is closely related to lightning

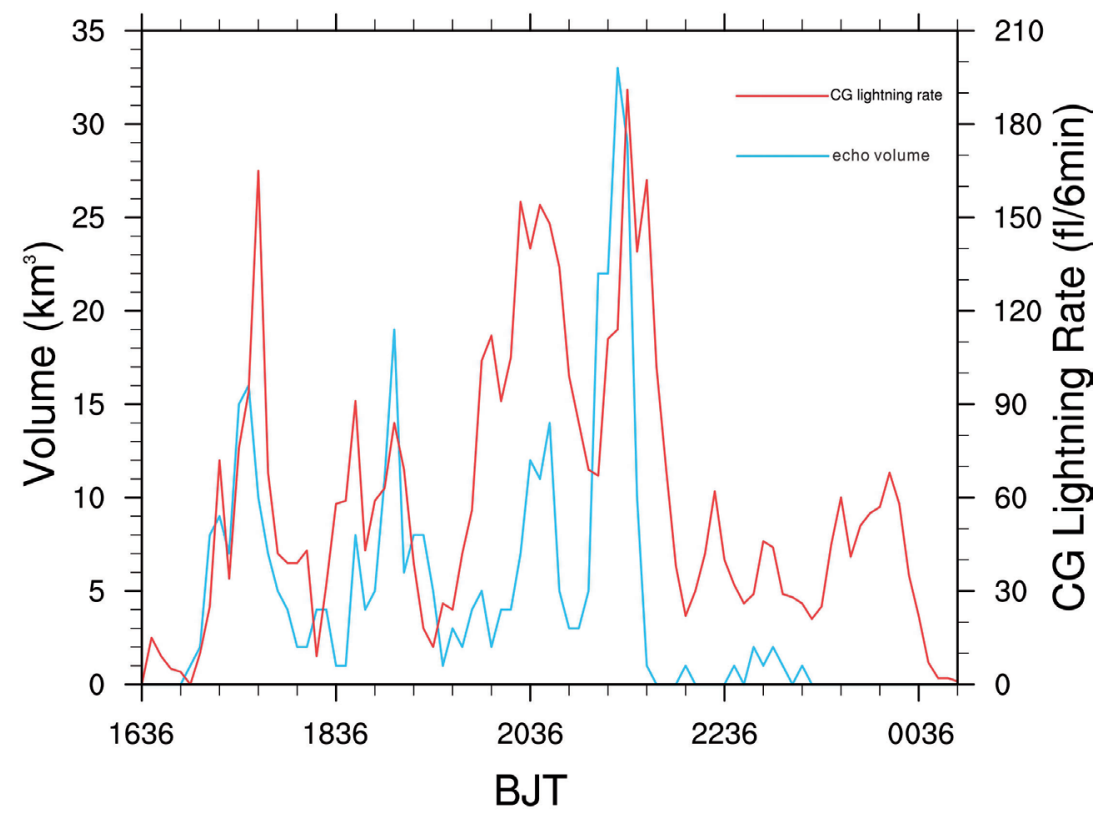

Fig. 3. Evolution of strong echo volume above the freezing level and the CG lightning rate. 
activity [63-64]. Focusing on the understanding of the linkage between CG lightning and the microphysical properties in convective cloud, we show the superposition of CG lightning with hydrometeors at $3 \mathrm{~km}$ AGL, under the freezing level, in the four peakactivity cases in Fig. 4. The symbol "+" indicates positive, and "-" the negative CG lightning flash. The result of hydrometeors classification shows that mainly liquid droplets is found in the thundercloud, i.e. drizzle rain and rain, at $3 \mathrm{~km}$ AGL. Solid ice particles, such as graupel, hail, snow and dry crystal, are displayed very few at this height, in comparison with the liquid water content. The CG lightning flashes correspond to the rain areas of strong echo very well. Both radar echo intensity and the strong echo area do not change significantly, which indicates the mature stage of thundercloud. The CG lightning flash occurs easily in mature convective cells. The strong convection facilitates the release of electric charge, increasing the probability of electric discharge. Zhang et al. [65] experimentally showed that the electric discharge in thunderclouds is largely dependent on the updraft; however, it also requires a certain concentration and a specific size of hydrometeors as well as a precipitation rate $\geq 5 \mathrm{~mm} / \mathrm{h}$ on the ground. In the thunderclouds, updraft, condensation and saturated ambience in the strong echo region is favourable to ice crystal riming. The latent heat release also provides energy for the development of a thunderstorm, is thereby a favourable environment for the CG lightning generation.

\section{At $6 \mathrm{~km}$ AGL}

In addition to the analysis of linkage of CG lightning activity and cloud microphysical properties in lower $3 \mathrm{~km}$ AGL, the linkage above the freezing level is of considerable importance in cloud microphysics study because it is hard to determine the height of electric discharging. Superimposed CG lightning flashes with the microphysical properties at $6 \mathrm{~km}$ AGL, above the freezing level, are shown in Fig. 5. The dominant hydrometeors in the thundercloud at $6 \mathrm{~km}$ AGL are dry snow, followed by wet graupel, dry graupel, wet snow and large hail. Large hail has a scattered distribution, whereas the distributions of dry and wet graupel are very consistent with the strong echo regions, which also sufficiently correspond with the CG lightning distribution. This shows that the presence of graupel particles is favourable to the occurrence of CG lightning. Lopez et al. [4] have pointed out that there is a close relationship between graupel content above freezing level and CG lightning activity. Bruning et al. [1], Dotzek et al. [2] and Lund et al. [3] have found that lightning occurs in or near the cloud layers which contain graupel particles. Although it is impossible to determine the initiation level of lightning with the radar data, the notable correspondence of CG lightning flash with graupel distribution shows the importance of graupel in lightning formation, which is consistent (a)

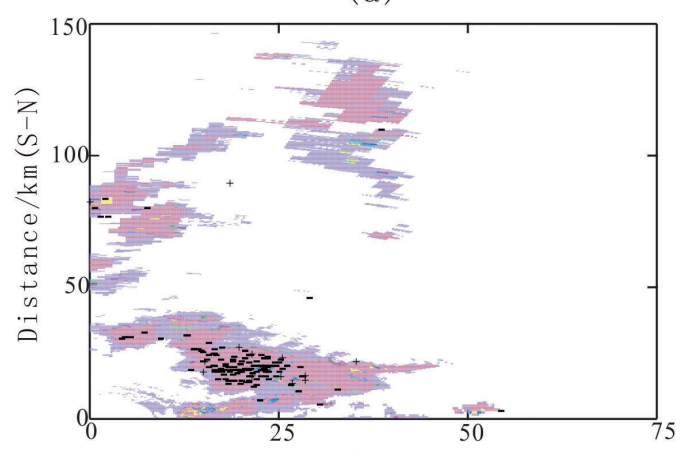

(c)

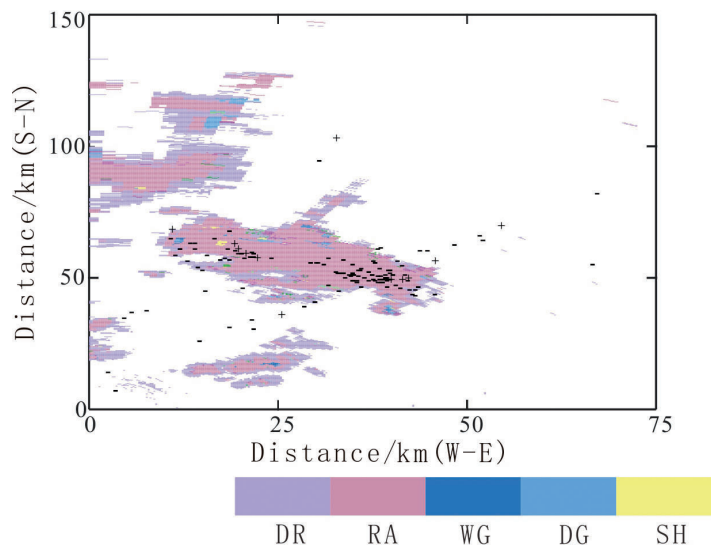

(b)

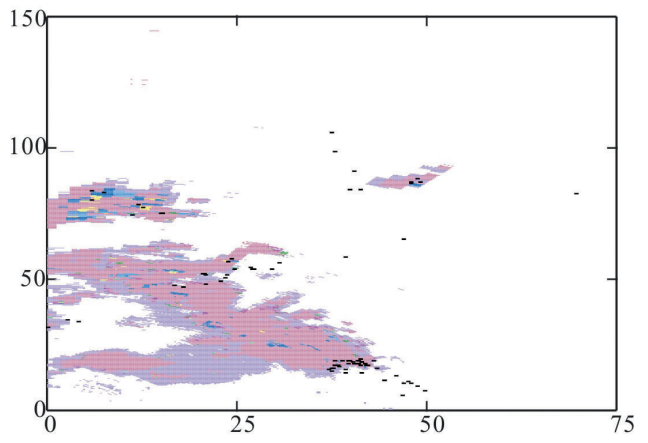

(d)

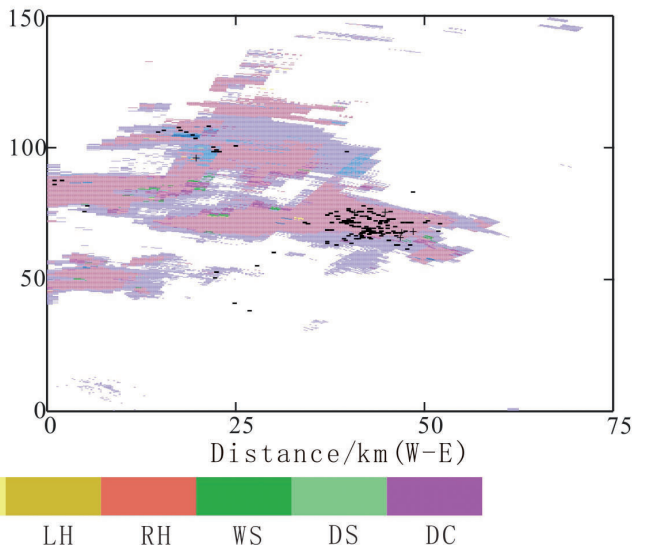

Fig. 4. Superposition of CG lightning and hydrometeors at $3 \mathrm{~km}$ AGL for four high-activity cases, a) 1748, b) 1848 , c) 2030 and d) 2136 BJT July 8 . 
(a)

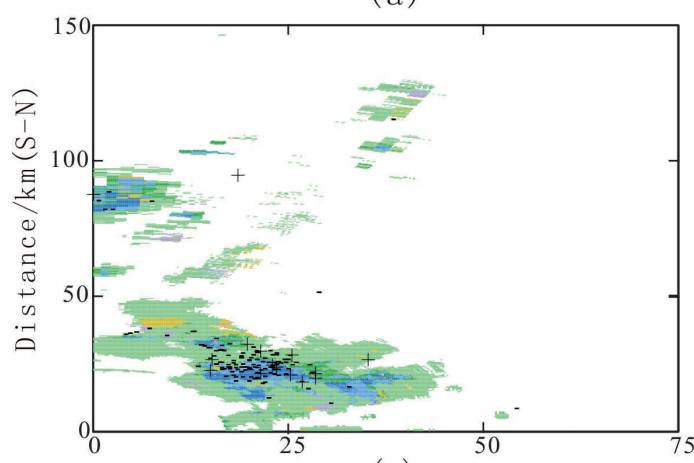

(c)

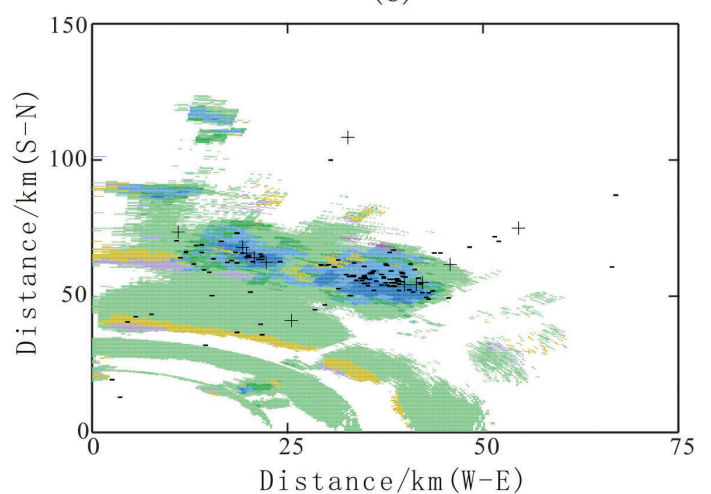

(b)

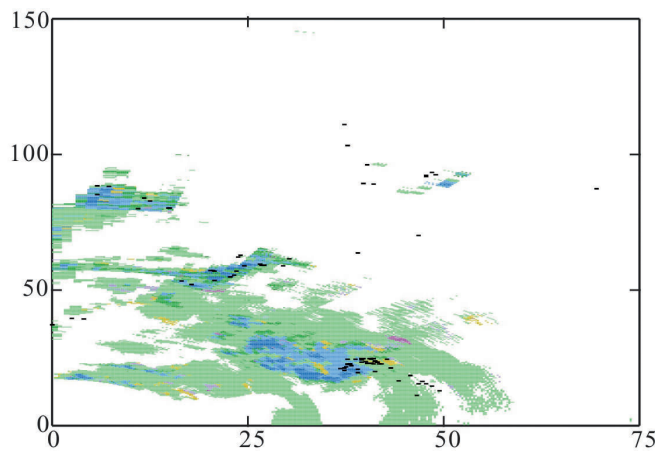

(d)

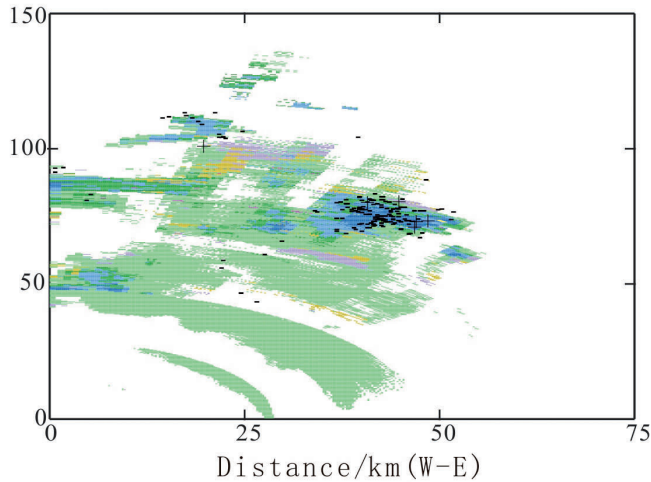

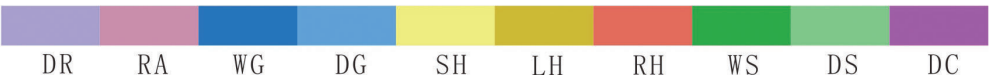

Fig. 5. Superposition of the CG lightning and hydrometeors at $6 \mathrm{~km}$ AGL in four high-activity cases, a) 1748, b) 1848 , c) 2030 and d) 2136 BJT July 8.

with the findings of previous studies.

\section{Vertical Coupling of the Lightning and Hydrometeors}

As observed from the vertical variation of cloud hydrometeors retrieved with the Doppler radar data, lightning flashes occurred in correspondence with different hydrometeors in different vertical levels. Water substance in convective clouds changes its phase with the height variation. For the objective display of the relationship between lightning activity and the microphysical properties, the vertical cross sections of radar reflectivity and hydrometeors at the azimuth of the largest CG lightning flashes are displayed in Fig. 6. The corresponding number of CG lightning flashes is plotted also to show the location coupling with hydrometeors. The selected azimuths are $49^{\circ}, 59^{\circ}, 33^{\circ}$ and $28^{\circ}$ respectively in the four cases, which correspond to 21 , 15, 22 and $34 \mathrm{CG}$ lightning flashes. The coordinate axis origin shows the location of the radar.

At the first peak time (1748 BJT, Fig. 6a), a strong echo region appeared at a horizontal distance of $20-40 \mathrm{~km}$ from the radar centre, with its top height exceeding $12 \mathrm{~km}$. Below the freezing level at $5 \mathrm{~km}$ AGL, the dominant hydrometeors were rain and drizzle rain (Fig. 6b). At about $3 \mathrm{~km}$ AGL, two small areas of dry crystals are detected on both sides of the rainfall area; wet graupel are observed at $4 \mathrm{~km}$ AGL in the rain band, $30 \mathrm{~km}$ away from the radar centre. At $5 \mathrm{~km}$ AGL, boundary between solid particles (include dry crystal, dry snow, dry graupel, wet graupel, wet snow) and rain is clear, which shows the transition zone of ice particle gradually transforming into liquid droplet. Above the level $5 \mathrm{~km}$ AGL, solid particles such as dispersed graupel, dry crystal, dry snow and wet snow are dominant. In the strong echo region, a large amount of wet or dry graupel is detected, which corresponds to the location of the CG lightning strikes at a horizontal distance of 20-40 km from the radar centre. Mainly dry crystal is found above $11 \mathrm{~km}$ AGL over the strong echo region. The CG lightning occurred at where the strong echo is observed.

In Fig. 6c) showing case 1848 BJT, the echo intensity increases to more than $45 \mathrm{dBZ}$ when moved outward from the radar. A small area of strong echo appears at 5-6 km AGL (Fig. 6d), just above the strong echo body in low level, which corresponds to graupels over rain layer of strong reflectivity. A large area of drizzle and a small amount of falling dry snow is observed around the rain zone. Resulting from the drag effect of rainwater, graupel particles appear near $3 \mathrm{~km}$ AGL. Large amount of dry crystal and dry snow are identified above the freezing level, while the strong echo region 
(a)

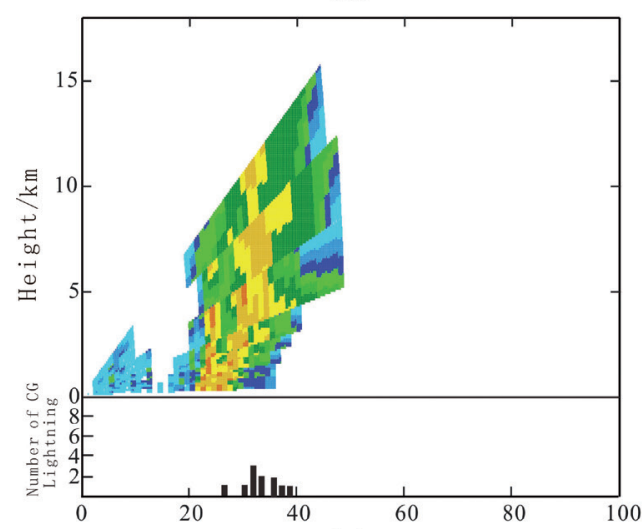

(c)

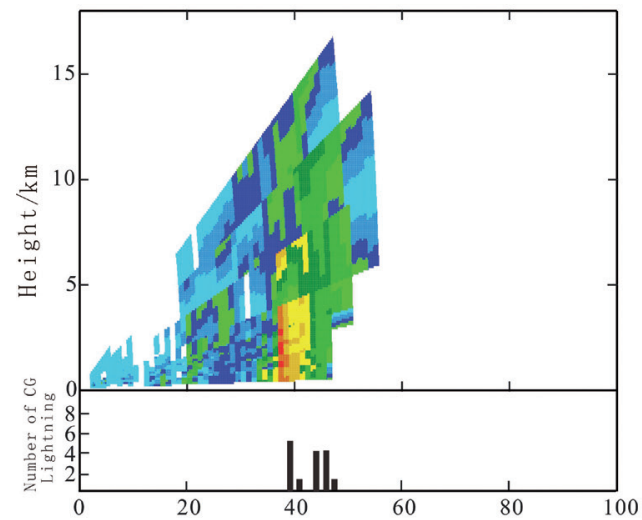

(e)

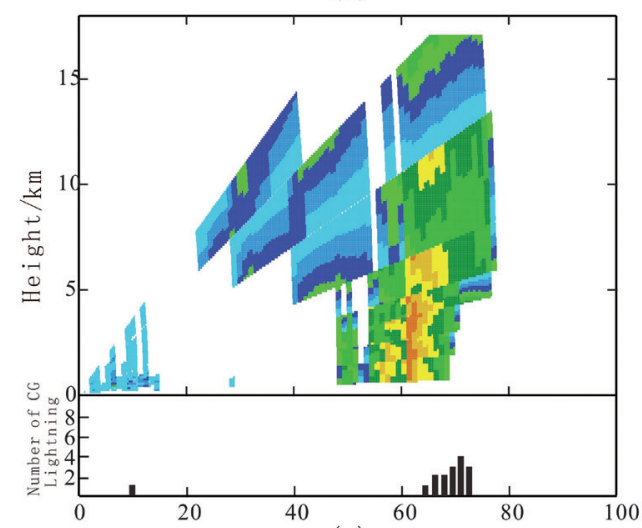

(g)
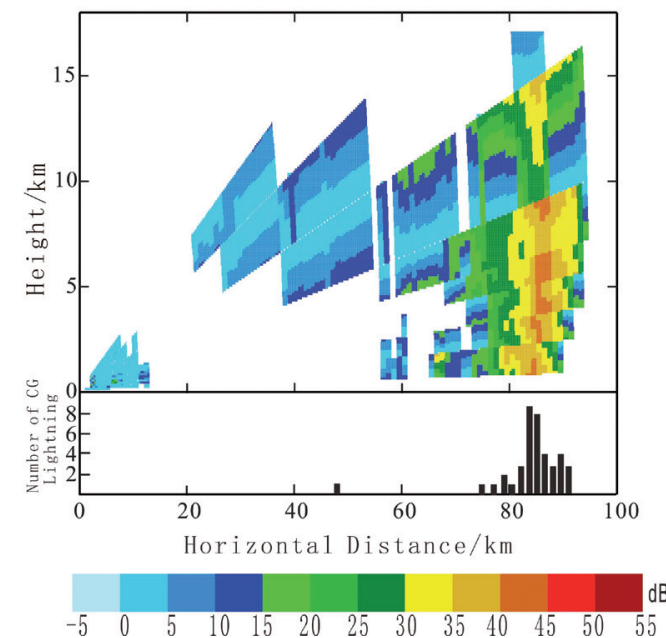

(b)

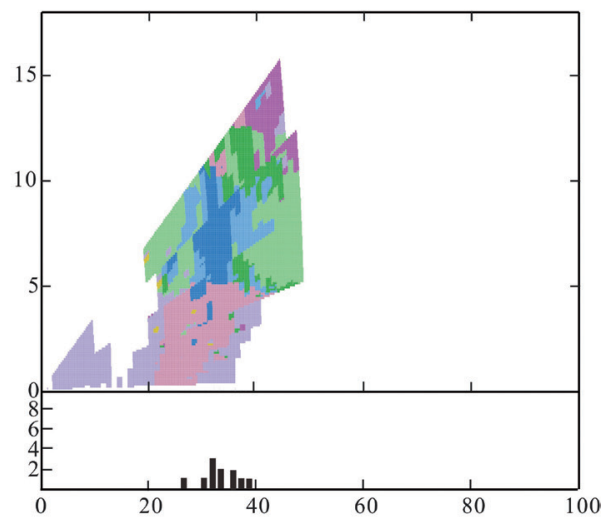

(d)

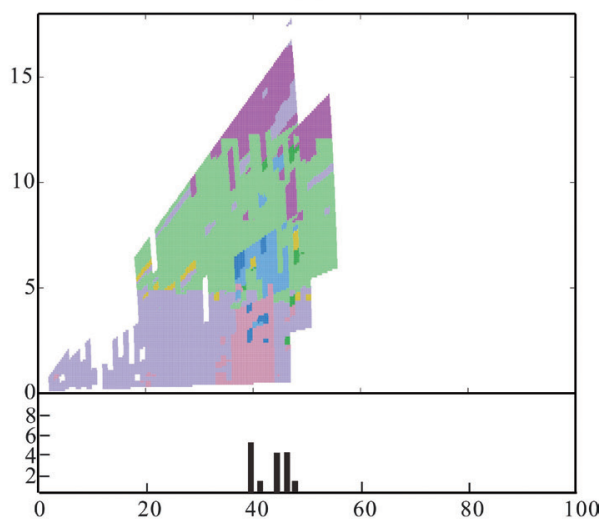

(f)

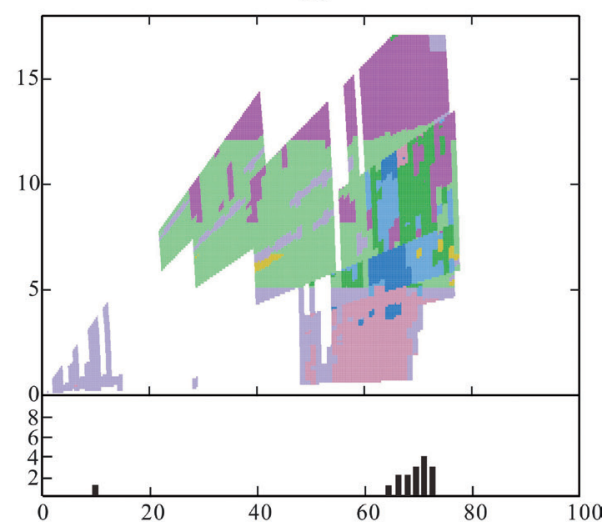

(h)

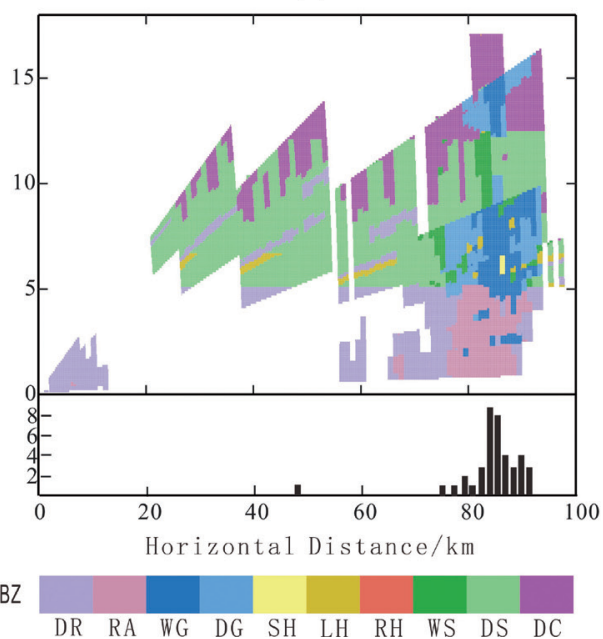

Fig. 6. Vertical cross section of radar reflectivity (left), classified hydrometeors (right) and the number of CG lighting flashes in the four high-activity cases, (a, b) 1748, (c, d) 1848, (e, f) 2030 and (g, h) 2136 BJT July 8. 
is dominated by graupel with small amounts of rain, wet snow and hail. The CG lightning flashes shows its location at the strong echo region, where strong convection is illustrated in the Fig. 6d).

At 2030 BJT (Figs 6e and 6f), the strong echo region moved to about $55-65 \mathrm{~km}$ away from the radar. The strong intensity of radar reflectivity exceeds $40 \mathrm{dBZ}$ in Fig. 6e). The strong echo increases in size and height, reaching an elevation of about 9-11 km AGL. As shown in Fig. 6f), rain is the dominant, with small amounts of drizzle rain, melting snow, dry graupel and wet graupel below $5 \mathrm{~km}$ AGL. The $0^{\circ} \mathrm{C}$ level is shown as a transition zone where dry crystal, dry snow, graupel particles and a little rain and hail transform to rain. Above $5 \mathrm{~km}$ AGL, dry crystal and dry snow are however the dominant particles, and wet and dry graupels are also shown in the strong echo region.

One hour later (Figs $6 \mathrm{~g}$ and $6 \mathrm{~h}$ ), when the strongest CG lightning activity appeared, the strong echo scale grew much larger than in the preceding time. The strong echo moved to $80-90 \mathrm{~km}$ away from the radar, with a body height more than $15 \mathrm{~km}$. Similar hydrometeor distribution is shown as that in the preceding timeinstants. A lot of rain and drizzle is identified below the freezing level, with a few dry crystals on both sides of the rain belt. A few wet and dry graupel particles is displayed in the strong echo region. Above $5 \mathrm{~km}$ AGL, however, large amount of dry crystal and dry snow particles present. Area of the dry and wet graupel region enlarges as consequence of the strong echo enhancement, when large and small hails appear around graupel particles in Fig. 6h). Much higher CG lightning frequency is shown in Fig. 6h) at the strong echo position, which indicates electric charging in association with the graupel in convective cloud.

The comprehensive analysis of the relationship between the observed radar reflectivity, hydrometeor distribution and CG lightning activity in the four cases shows that CG lightning flashes generally take place in region of radar reflectivity $25-40 \mathrm{dBZ}$. In addition to rain droplet, solid particles such as graupel, wet snow, dry snow and dry crystal are found in the strong echo region above the freezing level in the hydrometeor classifications. High concentration of CG lightning is largely consistent with the area dominated by graupel particles and the horizontal position of the strong echoes. The result is in accordance with Zhang et al. [33] that the electric discharge of thunderclouds is largely dependent on the updraft. A certain concentration and specific size of hydrometeors as well as a precipitation rate $\geq 5 \mathrm{~mm} / \mathrm{h}$ on the ground, are still required. Large amount of rain droplets is present in the low levels of the strong echo region. The abundance of liquid droplets in those areas provides favourable conditions for the growth of ice crystals; the latent heat release provided energy for the thunderstorm development. Meanwhile, the upper levels of the strong echo region above the $0^{\circ} \mathrm{C}$ isotherm is basically of mixed ice-phase particles.
The non-inductive electrification process, which occurs as these large and small ice phase particles collide, is the most important electrification mechanism in thunderclouds. It can produce highly intensive electric field for lightning flashes. The combination of these conditions provides a particularly suitable environment for the generation of $\mathrm{CG}$ lightning during this thunderstorm process. The close spatial and temporal relationship among the observed radar reflectivity, hydrometeor distribution and the CG lightning activity indicates the hydrometeor classification being credible.

\section{Conclusions}

Synthesis of the X-band dual-polarization radar parameters and ambient temperature and the preprocessed $Z_{\mathrm{H}}-\mathrm{K}_{\mathrm{DP}}$ correction is successfully used to the analysis of the cloud hydrometeors classification and the relationship to CG lightning activity. The relationship between the CG lightning activity and hydrometeor properties during a typical thunderstorm in Sichuan basin, China on July 8, 2013 is comprehensively analysed using the fuzzy logic algorithm method. We can conclude as,

1. Negative $C G$ lightning flashes mostly occur in the 30-45 dBZ echo region, while positive CG lightning flashes mainly occur at the fringes of the strong echo region, where the echo value shows to be $25-35 \mathrm{dBZ}$.

2. Above the freezing level, $C G$ lightning flash activity is quite consistent with the change of strong echo volume which shows a little leading time to the variation of flash activity. The temporal evolution of the strong echo volume is an indicator of the enhancement and attenuation of the CG lightning activity, and the strong echo volume above the $0^{\circ} \mathrm{C}$ isotherm are one of the important factors to predict the CG lightning activity in Sichuan basin.

3. Below the freezing level, liquid phase droplets, such as drizzle rain and rain, are the dominant in thunderclouds as shown in the identification result in Sichuan basin, China. The CG lightning occurs at the location of strong-echo rainfall areas in thunderclouds. Mainly dry snow appears above the $0^{\circ} \mathrm{C}$ isotherm in thunderclouds, and graupel is dominant at the location of CG lightning flashes with strong convection. Mixed ice-phase particles are shown nearby. The graupel region above the freezing level significantly coincides with high CG lightning activity. In general, the CG lightning activity is strongly correlated with the graupel domination of ice-phase particles in convective area of thunderclouds.

4. Analysis of hydrometeor particle distribution with the vertical cross section across the maximum CG lightning activity shows complex phase change of hydrometeors in thunderclouds. The $0^{\circ} \mathrm{C}$ level, at $5 \mathrm{~km}$ AGL in Sichuan basin, is a zone in which 
ice-phase particles change into liquid droplets. Below the freezing level, the strong echo region shows rain, whereas it displayed to be dry and wet graupel above the level. From top to bottom, the hydrometeor is generally in form of dry crystal, dry snow, wet snow, dry and wet graupel, and rain or drizzle liquid droplet in thunderclouds. The non-inductive electrification between different ice phase particles is the significant trigger of strong CG lightning activity. Strong CG lightning activity corresponds to a high cloud top and a large area of graupel particle region. The area of mixed-phase ice particles, especially dry and wet graupel, can be regarded as an important indicator of the time and location of $\mathrm{CG}$ lightning activity in thunderclouds.

Even though the results are based on only one single case study, it can provide a valuable reference for early warning and forecasting of imminent lightning disasters. Further investigation of the fuzzy logic algorithm-based hydrometeors classification, incorporating with the T-type membership functions and optimization of weight of individual parameter, serves to improve the X-band dual-polarization radar data analysis. Unfortunately, inherent limitations to the available observation currently preclude verification of the hydrometeor classification.

\section{Acknowledgements}

Thanks to Professor Y. Zhou for his valuable discussion on this research. We appreciate the reviewers' constructive comments to improve the paper. This study is funded by the Chinese Desert Meteorological Science Research Found (Sqj2019013), the National Natural Science Foundation of China (41875083 and 41905084), the Science and Technology Development Fund Project of Heavy Rain and Drought-Flood Disasters in Plateau and Basin Key Laboratory of Sichuan Province (2018-18) and the Scientific Research Project of China Meteorological Administration Training Centre

\section{Conflicts of Interest}

The authors declare no conflict of interest.

\section{References}

1. WANG C.X. The Relationship between Vertical Airflow Characteristics and Lightning Activity of Thunderstorm[D]. Beijing: Chinese Academy of Meteorological Sciences, 2014.

2. WANG F., ZHANG Y.J., ZHENG D., XU L.T. Impact of the vertical velocity field on charging processes and charge separation in a simulated thunderstorm $[\mathrm{J}]$. Journal of Meteorological Research, 29 (2), 328, 2015.
3. WANG F., ZHANG Y.J., ZHENG D. Impact of updraft on neutralized charge rate by lightning in thunderstorms: A simulation case study[J]. Journal of Meteorological Research, 29 (6), 997, 2015.

4. LIANG M.X., GUO F.X., WU.X., JIANG T., SHI H.F. Numerical Simulation of Influence of Relative Growth of Ice and Graupel on Noninductive Electrification [J]. Plateau Meteorology, 2016.

5. BABICH L.P., BOCHKOV E.I., NEUBERT T. The role of charged ice hydrometeors in lightning initiation [J]. Journal of Atmospheric and Solar-Terrestrial Physics, 154, 43, 2017.

6. BABICH L.P., BOCHKOV E.I. Initiation of Positive Streamers near Uncharged Ice Hydrometeors in the Thundercloud Field [J]. Plasma Physics Reports, 44 (5), 533, 2018.

7. GUO F.X., LU G.Y., WU X., WANG H.L., LIU Z.P., BAO M., LI Y.W. Occurrence conditions of positive cloud-toground flashes in severe thunderstorms. Science China Earth Sciences, doi: 10.1007/s11430-016-5279-7, 2016.

8. MA M., LIN J.B., FU Y.F. A study of lightning and precipitation profiles of a severe convective activity[J]. Acta Meteorologica Sinica, 70 (4), 797, 2012.

9. XIA H.M. The relationship between lightning and icephase particles based on the TRMM satellite and its application in lightning data assimilation[D]. Lanzhou: Lanzhou University, 2017.

10. WANG F., ZHANG Y.J., ZHENG D., XU L.T., ZHANG W.J. Semi-idealized modelling of lightning initiation related to vertical air motion and cloud microphysics[J]. Journal of Meteorological Research, 31 (5), 976, 2017.

11. GUO F.X., HUANG Z.C., WANG M.F., numerical simulation of micro-physical and electrical characteristics of a thunderstorm in Guangdong China[J]. Journal of Tropical Meteorology, 5, 626, 2018.

12. BRUNING E.C., RUST W.D., SCHUUR T.J., MACGORMAN D.R., KREHBIEL P.R., RISON W. Electrical and polarimetric radar observations of a multicell storm in TELEX. Monthly Weather Review, 135 (7), 2525, 2007.

13. DOTZEK N., HÖLLER H., THÉRY C., FEHR T. Lightning evolution related to radar-derived microphysics in the 21 July 1998 EULINOX supercell storm. Atmospheric Research. 56 (1-4), 335, 2001.

14. LUND N.R., MACGORMAN D.R., SCHUUR T.J., BIGGERSTAFF M.I., RUST W.D. Relationships between lightning location and polarimetric radar signatures in a small mesoscale convective system. Monthly Weather Review. 137 (12), 4151, 2009.

15. LÓPEZ R.E., AUBAGNAC J.P. The lightning activity of a hailstorm as a function of changes in its microphysical characteristics inferred from polarimetric radar observations. Journal of Geophysical Research: Atmospheres. 102 (D14), 16799, 1997.

16. WEN G., PROTAT A., MAY P.T., WANG X., MORAN W. A cluster-based method for hydrometeor classification using polarimetric variables. Part I: Interpretation and analysis. Journal of Atmospheric and Oceanic Technology. 32 (7), 1320, 2015

17. GUO F.X., MA X.Q., WANG T., CHEN C. An approach to the hydrometeors classification for thunderclouds based on the X-band dual-polarization Doppler weather radar[J]. Acta Meteorologica Sinica, 2014.

18. FAN P., WANG J.H., CHEN J. Particle Identification Based on Fuzzy Logic Method[J]. Journal of Henan Normal University(Natural Science Edition), 2016. 
19. SHI Z., FAN K.B., LI X.H., WANG X. Study of detection capability of X-band fully solid-state weather radar on precipitation[J]. Transactions of Atmospheric Sciences, 36(3):379-384, 2013.

20. LI B., GU Q.T., LI R.Y., CAO J.W., WANG X. Analyses on disastrous weather monitoring capability of CINRAD and future development[J]. Meteor Mon. 39 (3), 265, 2013.

21. CHEN X., ZHAO K., XUE M. Spatial and temporal characteristics of warm season convection over Pearl River Delta region, China, based on 3 years of operational radar data[J]. Journal of Geophysical Research: Atmospheres, 119 (22), 12,447-12,465. 2014.

22. WU L.L., LIU L.P., YUAN Y., JI L., LI M.Y. Study on Z_(DR) Processing Algorithm of C- Band Mobile Dual Polarization Radar[J]. Plateau Meteorology, 34 (1), 279, 2015.

23. WANG M.J., ZHAO K., XUE M., ZHANG G.F., LIU S., WEN L., CHEN G. Precipitation microphysics characteristics of a Typhoon Matmo (2014) rainband after landfall over eastern China based on polarimetric radar observations[J]. Journal of Geophysical Research: Atmospheres, 121 (20), 12,415-12,433, 2016.

24. CHU Z.G., HU H.F., HUANG X.Y., WEI M. The Narrow Beam C-Band Dual-Polarization Doppler Weather Radar of NUIST and Its Performance Analysis[J]. Plateau Meteorology, 36 (4), 1072, 2017.

25. QIE X.S., ZHANG Y.J. A Review of Atmospheric Electricity Research in China from 2011 to 2018[J]. Advances in Atmospheric Sciences, 36 (9), 994, 2019.

26. VIVEKANANDAN J., ELLIS S.M., OYE R., ZRNIC D.S., RYZHKOV A.V., STRAKA J. Cloud microphysics retrieval using $S$-band dual-polarization radar measurements. Bulletin of the American Meteorological Society, 80, 381, 1999.

27. LIU H.P., CHANDRASEKAR V. Classification of hydrometeors based on polarimetric radar measurements: Development of fuzzy logic and neuro-fuzzy systems, and in situ verification. Journal of Atmospheric \& Oceanic Technology, 17, 140, 2000.

28. HASSAN A.S., BOUMAHMOUD A.A., BÉATRICE F., FRASIER S.J. TABARY P. A New Fuzzy Logic Hydrometeor Classification Scheme Applied to the French $\mathrm{X}-, \mathrm{C}-$, and S-Band Polarimetric Radars[J]. Journal of Applied Meteorology \& Climatology, 52 (10), 2328, 2013.

29. THOMPSON E.J., RUTLEDGE S.A., DOLAN B.A., CHANDRASEKAR V. A Dual-Polarization Radar Hydrometeor Classification Algorithm for Winter Precipitation[J]. Journal of Atmospheric \& Oceanic Technology, 31 (7), 1457, 2014.

30. NICOLETTA R., LUCA B., ELISA A., LUCA F. A Support Vector Machine Hydrometeor Classification Algorithm for Dual-Polarization Radar[J]. Atmosphere, 8 (12), 134, 2017.

31. MARZANO F.S., SCARANARI D., VULPIANI G. Supervised fuzzy-logic classification of hydrometeors using C-band weather radars. IEEE Transactions on Geoscience and Remote Sensing, 45 (11), 3784, 2007.

32. CAO J., LIU L., GE R. A study of fuzzy logic method in classification of hydrometeors based on polarimetric radar measurement. Chinese Journal of Atmospheric Sciences, 29 (5), 827, 2005.

33. CHENG Z.J., L X.X., ZHU Y.P.A process of hydrometeor phase change with dual-polarimetric radar. Journal of Applied Meteorological Science, 20 (5), 594, 2009 [In Chinese].

34. PARK H.S., RYZHKOV A.V., ZRNIĆ D.S., KIM K.E. The hydrometeor classification algorithm for the polarimetric WSR-88D: Description and application to an MCS. Weather and Forecasting, 24 (3), 730, 2009.

35. ZHANG T.L., YANG J., CHU R. Z., ZHAO G., ZHANG T. Distribution of Precipitation Particle and Electrical Characteristic of a Thunderstorm in Pingliang Region [J]. Plateau Meteorology, 31 (4), 1091, 2012.

36. WANG D.W., LIU L.P., ZONG R. Fuzzy logic method in retrieval atmospheric cloud particle phases and effect analysis. Meteorological Monthly, 41 (2), 171, 2015.

37. RIBAUD J.F., BOUSQUET O., COQUILLAT S., HASSAN A.S. Evaluation and application of hydrometeor classification algorithm outputs inferred from multifrequency dual-polarimetric radar observations collected during HyMeX[J]. Quarterly Journal of the Royal Meteorological Society, 142 (S1), 95, 2016.

38. YANG X.L., SUN J.H. The characteristics of cloud-toground lightning activity with severe thunderstorm wind in South and North China[J]. Atmospheric and Oceanic Science Letters, 7 (6), 571, 2014.

39. WANG Y., YANG Y., WANG C.H. Improving forecasting of strong convection by assimilating cloud-to-ground lightning data using the physical initialization method[J]. Atmospheric Research, 150, 31, 2014.

40. XIA R.D., ZHANG D.L., WANG B.L. A 6-yr cloudto-ground lightning climatology and its relationship to rainfall over central and Eastern China. Journal of Applied Meteorology and Climatology, 54 (12), 2443, 2015.

41. XIE Y.R., WU J., LIU X.T., ZHANG T.F., XIE Y.J., XU Y.J., ZHAO D.M. Characteristics of cloud-to-ground lightning activity in hailstorms over Yunnan province. Journal of Atmospheric and Solar-Terrestrial Physics, 136, $2,2015$.

42. WU F., CUI X.P., ZHANG D.L., LIU D.X., ZHENG D. SAFIr-3000 lightning statistics over the Beijing metropolitan region during 2005-07. Journal of Applied Meteorology and Climatology, 55, 2613, 2016.

43. LI W.L., QIE X. S., FU S.M., SU D.B. SHEN Y.H. Simulation of quasi-linear mesoscale convective systems in northern China: Lightning activities and storm structure. Advances in Atmospheric Sciences, 33 (1), 85, 2016.

44. ZHENG D., ZHANG Y.J., MENG Q., CHEN L.W., DAN J.R. Climatology of lightning activity in South China and its relationships to precipitation and convective available potential energy. Advances in Atmospheric Sciences, 33 (3), 365, 2016

45. ZHANG T.L., ZHAO G., WEI C.X., GAO Y., YU H., ZHOU F.C. Relationships between cloud-to-ground flashes and hydrometeors in a thunderstorm in Fujian province. Journal of Atmospheric and Solar-Terrestrial Physics, 154, 226, 2017

46. XIAO Y.J., LIU L.P. Study of methods for interpolating data from weather radar network to 3-D grid and mosaics. Acta Meteorologica Sinica. 64 (5), 647, 2006.

47. BRINGI V.N., CHANDRASEKAR V. Polarimetric Doppler weather radar: principles and applications. Cambridge university press. 2001.

48. ZRNIĆ D.S., RYZHKOV A., STRAKA J., LIU Y., VIVEKANANDAN J. Testing a procedure for automatic classification of hydrometeor types. Journal of Atmospheric and Oceanic Technology, 18 (6), 892, 2001.

49. AL-SAKKA H., BOUMAHMOUD A.A., FRADON B., FRASIER S.J., TABARY P. A new fuzzy logic hydrometeor classification scheme applied to the French X-, C-, and S-band polarimetric radars. Journal of Applied Meteorology and Climatology, 52 (10), 2328, 2013. 
50. WU C. Data Quality Analysis,Hydrometeor Classification and Mosaic Application of Polarimetric Radars in China[D]. Nanjing: Nanjing University of Information Science and Technology, 2018.

51. HE Y.X., XIAO H., LV D.R. Polarization Radar Analysis of Characteristic Distribution of Water Condensate Particles in Stratiform Clouds.Chinese Journal of Atmospheric Sciences, 31 (4), 1091, 2010.

52. KEENAN T.D. Hydrometeor classification with a C-band polarimetric radar. Australian Meteorological Magazine, 52 (1), 23, 2003.

53. LIU Y.N., XIAO H., YAO Z.D., FENG L. Analyses of hydrometeor identification based on X-band polarimetric radar [J]. Climatic and Environmental Research, 17 (6), 925, 2012.

54. HU Z.Q., LIU L.P., CHU R.Z. Comparison of different attenuation correction methods and their effects on estimated rainfall using X-band dual linear polarimetric radar. Acta Meteorologica Sinica. 66 (2), 251, 2008.

55. ZHANG T. L., YANG J., CHU R.Z., ZHAO G., ZHANG T. Distribution of precipitation particle and electrical characteristic of a thunderstorm in Pingliang region. Plateau Meteorology, 31 (4), 1091, 2012.

56. LI J.H., LIANG G.X., AN X.W. Relationship of cloud-ground lightning activities with radar echo and precipitation in storms of Beijing. Journal of Nanjing Institute of Meteorology, 29 (2), 228, 2006.

57. MU J.L., LI Z.C., SHEN Y. Characteristics of ground lightning and relationships of mesoscale convective systems and heavy rainfall in a strong rainstorm. Meteorological Monthly, 38 (1), 56, 2012.
58. WU X.K., YUAN T., LIU D.X., FENG G.L. Study of the Relationship between Cloud-to-Ground Lightning and Radar Echo of a Severe Squall Line in Shandong Peninsula[J]. Plateau Meteorology, 32 (2), 530, 2013.

59. LAI Y., ZHANG Q.L., CHEN H.B., LI Z.M., QI J.R. Analysis of the relationship between cloud-to-ground flash frequency and radar echo during a severe squall line in Shenzhen[J]. Journal of Tropical Meteorology, 2015.

60. CAREY L.D., MURPHY M.J., MCCORMICK T.L., DEMETRIADES N.W. Lightning location relative to storm structure in a leading-line, trailing-stratiform mesoscale convective system. Journal of Geophysical Research: Atmospheres, 110 (D3), 2005.

61. XU S. Lightning Activity of Hailstorms in Beijing-Tianjin Region[D]. Nanjing: Nanjing University of Information Science and Technology, 2016.

62. XU S., ZHENG D., WANG Y.Q., HU P.Y. Characteristics of the two active stages of lightning activity in two hailstorms[J]. Journal of Meteorological Research, 30 (2), $265,2016$.

63. QIE X.S., ZHANG Y.J., ZHANG Q.L. Study on the characteristics of lightning discharges and the electric structure of thunderstorm. Acta Meteorologica Sinica, 63 (5), 646, 2005.

64. ZHENG D., ZHANG Y.J., MENG Q., LV W.T., YI X.Y. Total lightning characteristics and electric structure evolution in a hailstorm. Journal of Meteorological Research, 23 (2), 233, 2009.

65. ZHANG Y., YAN M., LIU X. Simulation study of discharge processes in thunderstorm. Chinese Science Bulletin, 44 (22), 2098, 1999. 
